in-Dumartats: Leclece, if and Hourau 1919731 Arch Hydrabiol. Suppl. 39, 317-332

44 Allen. M.M. and Smith, A.1.11969, Arch Mikrobrot. 69.114-120

45 Yamanakd, C. and Clazer. A.N. 11980) Arch. Mikrabiol. 124, 39-47

46 Wman, M. Giegory. R.P.F. and C.art. NC. (1985) Science 230. 818-820

47 Dainippon Int and Chemıcals inc. (1979) laparsese Patent 79076867

48 Oainupjom Int diud Ctronic ais inc. (1979) laparese Patenl 95770

49 Dainıpon Ink and Chemicals inc. (1979) lapanese Patent 138156

50 Dainippon Int and Chemicals Inc. (1980) Japanesc Patent 077890

51 Duinippon ink and Chemicals inc. (1981) fapanese Parent 5605 14

52 Daintppon Ink and Chemic als Inc. (1987) lapanese Patent Of 691
53 Dainippon Ink and Chemicais Inc (1988) Japanese Patemt 8.3170

54 Dainıpoon ink and Chemicals Inc. (1989) Japunese Patent 123865

55 Nisshin Oil Mills In 1198 ) lapanere Patent 62215394

56 Institut francase du Pitrole (1980) French Patem 2453199

57 Ka Soap K. K (1981) Japance Patent 81005143

38 Ainomoto K.K. (197d) Japancse Pairent 53101575

59 Kanunakaran. A and Schick, B (1990) Cosmer. foiketices 105, 9 -88

60 Naki, S., Ogawd, H., Oahux, I., Veno, I. Soito, M. Imayoshi. I. and Kayama. M. (1982) Bull. tap. Sox. SCi. Fish 48. 647-65)

61 OH, V T, Clazer, A.N. and Sirver, L. (1982) / Cell Biol. 93, 981-986

62 Anon. (1978) lapan Chemic di Weak 2I December, p. 6

63 Bioconsult (1991) Apro-Ind. Hi Terh 2, 50-52

\title{
Viewpoint
}

The pleasure response to palatable foods, notably those rich In sugar and fat, may be mediated through the endogenous opioid peptide system. In a recent study, infusions of the opioid antagonist naloxone were shown to reduce taste preferences for sugar-fat mixtures and to decrease the consumption of sweet and high-fat foods. The effects were more pronounced among women characterized as compulsive 'binge-aters' than among control subjects. Cravings by obese or bulimic women for chocolate and other sweet, fat-mich desserts may be under opioid control.

Endogenous op,oid peptides are involved in the regulation of energy intake both in humans and in rats. Opioid peptides may influence food intake by mediating the pleasure response to foods. It has been proposed that the sensory pleasure response to foods is largely brought about by the release of endogenuus opioid peptides in the brain'. The blockade of opioid receptors by the adninistration of opioid antagonists (see Glossary) would thus be expected to reduce taste preferences and the pleasure response to foods and. consequently. to diminish the cumsumption of preferred fouds. Indeed. the opioid antagonists naloxone and naltrexone have been found to reduce food consumption in rats and mice'; such effects appear to be most pronounced for the best-tasting foods. Naloxone and naltrexone selectively reduced the consumption of a fat-rich diet by laboralory rats and prevented the development of obesity'; conversely, opioid agonists such as morphine or butorphanol selectively increasei the consumption of dietary fat". Some researchers believe that the primary role of the opioid peptide system is tu mediate overeating associated with exposure to pjeasant-tasting sweet or high-fat foods:.

Adan Drewnousti is Dirextor of the Hurman Niufrilon Program, Unix wity of Michogan School of Rublic thedith, Ann Arbor. Ml 48109-2029. L'SA.

\section{Food preferences and the opioid peptide system}

\section{Adanı Drewnowski}

\section{Opioid peptides and taste preferences}

Early studies on opioids and taste preferences dealt almost exclusively with preferences for sweet taste and the consumption of sweet solutions. Preferences for sweet taste appeared to be under opioid control. Studies on rats showed that opioud antagonists most effectively reduced intakes of preferred sweet liquids such as glucose, sucrose or saccharin solutions ${ }^{2}$. In addition, limited studies on human subjucts showed that oral doses of naltrexone reduced the pleasantness ratings of sucrose solutions and diminished th: acceptability of food odors".

More recerit studies on human taste preferences have focused on the role of fats in determining food accoptability and fuod consumption. Typical stimuli studied were basically mixtures of sugar and far, including milk shakes, rake frostings, cream cheese and ice cream' ? Studies on animals have suggested that preferences for dietary fats may also be under opioid control. In one study, the consumption of chocolate milk or chocolate candy by rats caused increased release of the opioid peptide $\beta$-eidorphin ${ }^{10}$. In other studies, infusions of sucrose or fat increased analgesia thresholds (the ability to withstand pain) in infant rats, also suggesting an incrcase in opioid release in response to the sugar or fat infusion".

\footnotetext{
Glosery

Opioid antronists: Lrups that counter act the effects of opoinds. such a naloxone, nalturexone and nalmetene.

Opiaid araistr: Drugs that mimic the effects of opioids, such as mophine and butor sin and
} 
The recent study by Drewnowski et al. " was the firs: to examine the effects of opioid blockade on human taste preferences for and consumption of mixnures of sugar and fat. Female subjects receiving intravenous naloxone infusions tasted 20 sweetened dairy products with different sugar and fat contents, and rated the 'sweetness' and 'pleasantness' of each cample. Naloxone had no effect on the perception of sweetness intensity. However. 'pleasantness' ratings for all the products were reduced relative to the ratings of subjects given a control infusion of saline. suggesting that opioid block ade does reduce the sensory pleasure response to both sweet and high-fat foods.

\section{Opioid peptides and food consumption}

Studies on human subjects have previously shown that opioid blockade leads to a reduction in food intake In clinical studies, naloxone reduced meal consumption by nomal-weight and obese subjects, and diminished the amount of food consumed during 'binges' by female subjects with bulimia'. Other studies have demonstrated that the opioid antagonists naltrexone and nalmefene reduced energy intakes during a lunch-time meal' 14 . Conversely, butorphanol injections led to an increase in the consumption of sandwiches, as measured in the laboratory over a six-hour period"s. The effects of naloxone on specific foods were not sysiematically measured: however, one study reported that nalmefene selectively reduced the lunch-time consur.uption of the subjects' mnst preferred foods, regardless of nutrient composition".

Sweet desserts rich in both sugar and fat are among the most palatable foods in the Westem diet. Such highly preferred foods are i aquently the object of food cravings

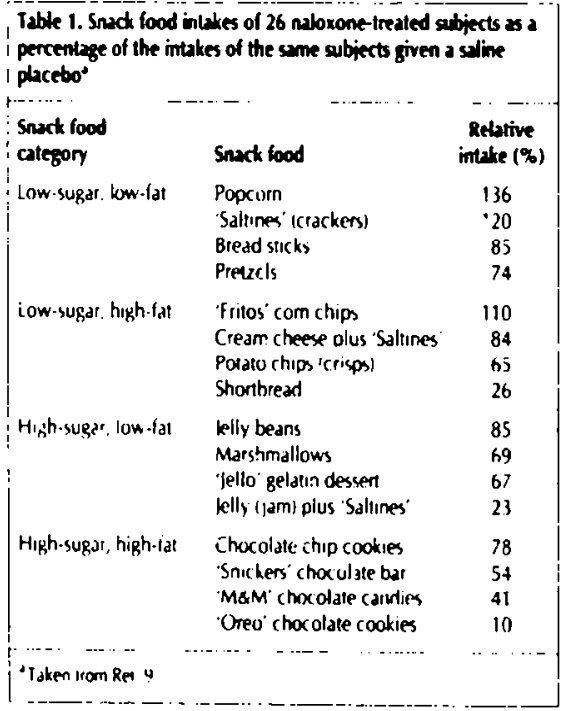

and feature prominently in reports of eating binges and food 'addictions': chocolate, in particular, is the most common object of food cravings by women ${ }^{16}$. Consequently, the most pronounced effects of opioid peptides on food intake might be expected $\omega$ be obtained for foods rich in sugar and fat, and especially for foods containing chocolate: accordingly, it might be expected that opioid blockade would selectively reduce the rewand value of highly palatable foods and, thus, selectively diminish their consumption.

A recent study" tested the effects of naloxone infusions on the consumption of 16 common snack foods. divided into four categories according to their sugar and fat contents. As shown in Table 1, pronounced effocts of naloxone were observed for the foods rich in fat, sugar. or both. On the other hand, in contrast to previous results'., there was no significant correlation between the magnitude of the effects of naloxone and preference ratings for the different foods. Intakes of some of the most highly rated foors (e.g. popcom) were actually increased by naloxone. Other studies have also suggested that opioid blockade increases the intake of bland carbohydrate-rich foous ${ }^{13}$. The effects of naloxone on food intake were not mediated by changes in hunger ratings, in contrast to the findings of other studies ${ }^{14}$ in which hunger ratings were affected by naloxone.

All four foods in the high-sugar, high-fat category happened to contain chocolate. As noted above, chocolate is probably the most common object of uncontrollable food cravings and food 'addictions" among women; furthermore. recent studies have specifically linked cravings for chocolate with the premenstrual syndrome ${ }^{10}$. If chocolate consumption leads to endogenous opioid peptide release in humans, as it does in rats ${ }^{10}$, then chocolate might be expected to act as a natural analgesic. The possibility that chocolate can reduce pain thresholds in humans is currently under investigation in our laboratory.

\section{Qpi:ind peptides in obesity and eating disonders}

Cravings for chocolate candy and ice cream have been frequently reported smong obese and dieting womer. and eating binges involving chocolate and ice cream are characteristic of compuisive eating behavior in subjects with bulimia nervusa. Both obese and bulimic women have been shown to have abnormal opioid peftide levels. It may be that the opioid peptide system plays a major role in mediating binge eating episodes among susceptible obese and bulimic individuals. Accordingly, maximal efrects of opioid blockade on food consumption are likely to be obtained among subjects showing a pattern of compulsive binge caring.

The recent study of Drewnowski et al. ${ }^{9}$ examined the effects of naloxone infusion on tood consumption in 14 women who were binge eaters and in 12 normal-weight female controls. Eight of the binge eaters were obese. Caloric intakes in binge eaters vere significantly re. duced in subjects given naloxone. relative to control subjects given saline. This reduction in food insake was not specific to any paricular macronutrient: intakes of 
carbohydrate, protein. and fat were all significantly reduced. However, the overall redurtion in intake was largely due to the reduces intake of sweet, high-fat foods: the intake of chocolate and cookies was reduced the most.

Abnormalities in the endogenous opioid peptide system may be linked to heightened sensory prefenences for sugar-fat mixtures and compulsive overeating of sweet. high-fat foods. Obvious parallels have been drawn between binge eating and drug addiction, since both behavioral syndromes involve intense cravings and loss of control. It may be that the same physiological mechenisms are involved in mediating food cravings and opiate reward. Both clinical observations and anecdotal reports indicate that sweet cravings tend to be associated with opiate addiction, while opiate withdrawal is sometimes alleviated by sweets ${ }^{17}$. The recent studies described above suggest that food cravings in obesity and eating disorders may be mediated by the endogenous opioid peptide system, which may explain the key sensory roles of dietary sugars and fat.

\section{References \\ 1 Cooper, S.I. and Kitham, I. (1990) in Opiouts, Bulmid and Akohol Aluse \& Akcholism (Reid. 1.0. ed 1, pp. 91-110. Springer. Verlat}

2 Ret, L.D. (19as) Am I Clin Nutr. 42, 1099-1132
3 Apfelbaur. M. and Mandenoff. A (1981) Pharmacd. Brochem. Betur. 15, 89-91

4 Marks-Kaufiman, R. and Kanurek, R B (1980) Pharmacol. Brochem. Behsv. $12,427-430$

5 P.mscs, D.R., Cosnell, B.A., Morky, IE and L evine, A.S. (1987) 1. Vurr. 117. 976-995

6 Fantino. M., Hoscate, I and Aptelbaum, M. (1986) Am. J. Phrsiol. 251, R91-R9s

7 Orewnowski, A. and Greenwood, M.R.C. (1983) Physiol. Behav. 30 , 629-633

- Drewnowskj, A., Bunzell, 1.D., Sande, K., Ivenus, P.H. and Greermood. M.R.C. (1985) Physiol. Behav. 35. 617-622

9 Drewmonski, A., Krahn, D.D., Demitrach MA. Naim, K and Cosnell, BA (1992) Physiol. Betur. 51 371-379

10 Dum. J. Gramsch. C. and Herz, A (1983) Pharmacal Brochem Behav $18,443-447$

11 Blass, EM 11987 ) in Sweetness (Dobbing I. ed.J. po. 115-126. Springer.Vertas

12 Mikchell, J.E., 1 dine, D.E., Morley, I.E. and Lev|ne, A.S. (Is86) Bual. Asychistry 21. $1399-1406$

13 Yeomans M.R. Winght, $P$, Maxime, HA and Cntchley, $|A| H$ (1990) Axchophamuxadogy (Bertin) 100, 426-432

14 Bertino, M. Beauchamp, G.K and Engelman, K. (1991) An. I Phrual 261, R59-R63

15 Morky, I.E, Parker, S and Levine, AS (1985) Am. I Clin. Nutr. 42 $1175-1178$

16 Rozin, P. Levine, E. and Stoess. C. 119921 Appetite 17, 199-212

17 Morabua, A, Fabre, I., Chee, E., Zegar, S., Orat, E. and Robert, A (1989) Br. I. Addiction 84, 173-180

\section{Book Reviews}

\section{As the edifars the in their iritroduction}

Numerous textbooks treat various as. pects of food chemistry and enguneering. yet little information is available on the process of industrial food research and development. Currenily, no texibooks of academic courses cover the broad area of product development. This roid keeps even the mos qualified person from reaclung an informed decision about a career in this fictd.

Attempting to fill this 'void', this book provides an interesting overview of the interface between food product development and the markeplace. It is dividad into 19 chapters, dealing with subjects ranging from market perspectives, con sumer research, R\&D. engineering. safety and logistics to quality assurance and rutritional aspects. The last lour chapters are mainly dedicated to peripheral issues: university-industry synergy. the protection of intellectual property. and 'turope 1992'. More futuristic chap. ers or. Tocal issues in tood science and engineering' and 'Suategies for global product development touch on many interesti.18 newer technologies such as

\section{Food Product Development: From Concept to the Marketplace}

edited by Emat Graf and !sael Sam Saguy, Van Nostrand Reinhold, 1991. \&39.60 (420 pages) SBN 0442001851

supercritical fluid extraction, irradiation, membrane processes and biotechnology.

The chapter by Ermst Giraf and Israel Sam Saguy on the 'R\&D process' is an interesting and fairhy cumplete survey of R\&D activities in the food business from the screening of ideas, through feasibility studies ano product development, to commercialization and, eventually, maintenance. However, it does not present a balanced view of the state of R\&D activity in the food industry. It is true that the tood industry spends a lower percentage of its sales income on R\&D than drug manulacturers do - but exciting and creative new research is still being carried out!

The book highlights some of the activities and skill requirements that are unique to an industrial food research career, as well as touchine on mamy different aspects of food pruduct devetopment, to show how the predominantty market-driven indusiry can deal with rapid changes by adapting existing products and technologies.

Some chapters are rather superficial ihus, although the bcok fulfits its purpose as stated in the introduction. its coverage cannol be regarded as exhaustive, as would be expected trom a lextbook it dres provide a very general overview ot the areas that would be of interest to those who do not know much aboun R\&D in the food industry. but need to get involved.

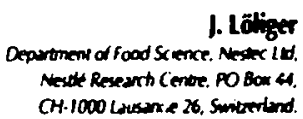

